Article

\title{
Identification of Potential Drug Targets in Helicobacter pylori Using In Silico Subtractive Proteomics Approaches and Their Possible Inhibition through Drug Repurposing
}

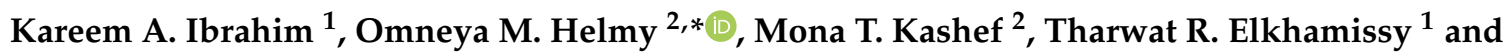 \\ Mohammed A. Ramadan ${ }^{2}$ \\ 1 Department of Microbiology \& Immunology, Faculty of Pharmacy, Egyptian Russian University, \\ Cairo 11829, Egypt; dr_kareem@windowslive.com (K.A.I.); prof.tharwat.elkhamisy@gmail.com (T.R.E.) \\ 2 Department of Microbiology \& Immunology, Faculty of Pharmacy, Cairo University, Cairo 11562, Egypt; \\ mona.kashef@pharma.cu.edu.eg (M.T.K.); m_ramdan56@hotmail.com (M.A.R.) \\ * Correspondence: omnia.helmy@pharma.cu.edu.eg
}

Received: 20 July 2020; Accepted: 10 September 2020; Published: 12 September 2020

\begin{abstract}
The class 1 carcinogen, Helicobacter pylori, is one of the World Health Organization's high priority pathogens for antimicrobial development. We used three subtractive proteomics approaches using protein pools retrieved from: chokepoint reactions in the BIOCYC database, the Kyoto Encyclopedia of Genes and Genomes, and the database of essential genes (DEG), to find putative drug targets and their inhibition by drug repurposing. The subtractive channels included non-homology to human proteome, essentiality analysis, sub-cellular localization prediction, conservation, lack of similarity to gut flora, druggability, and broad-spectrum activity. The minimum inhibitory concentration (MIC) of three selected ligands was determined to confirm anti-helicobacter activity. Seventeen protein targets were retrieved. They are involved in motility, cell wall biosynthesis, processing of environmental and genetic information, and synthesis and metabolism of secondary metabolites, amino acids, vitamins, and cofactors. The DEG protein pool approach was superior, as it retrieved all drug targets identified by the other two approaches. Binding ligands $(n=42)$ were mostly small non-antibiotic compounds. Citric, dipicolinic, and pyrophosphoric acid inhibited H. pylori at an MIC of $1.5-2.5 \mathrm{mg} / \mathrm{mL}$. In conclusion, we identified potential drug targets in H. pylori, and repurposed their binding ligands as possible anti-helicobacter agents, saving time and effort required for the development of new antimicrobial compounds.
\end{abstract}

Keywords: Helicobacter pylori; in silico; subtractive proteomics; drug targets; repurposing; chokepoint; database of essential genes; KEGG; BIOCYC

\section{Introduction}

Helicobacter pylori is one of the most common infectious agents in the world, colonizing more than half of the global population, especially in developing countries where over $80 \%$ of their population are infected [1]. Infection with $H$. pylori is easily transmitted by the fecal-oral route causing chronic active gastritis, dyspepsia, gastric mucosa-associated lymphoid tissue lymphoma, iron deficiency anemia, idiopathic thrombocytopenic purpura, and is the main cause of peptic ulcer and gastric carcinoma [2]. H. pylori has been identified, since 1994, as a class-1 carcinogen [3]; it is the primary identified cause of gastric cancer, which is the second most common cause of cancer-related deaths worldwide [4].

Treatment of $H$. pylori infection involves the use of antimicrobial combinations, including clarithromycin, azithromycin, metronidazole, amoxicillin, tetracycline, and levofloxacin along with 
a proton pump inhibitor and bismuth salts, for a treatment period of 7-14 days, and even more [5]. Adherence to therapy, in $H$. pylori infections, is the biggest issue in treatment failures alongside resistance development to the antimicrobial agents [6]. This is further complicated by the risk of re-infection, especially in areas with high $H$. pylori infection prevalence [7].

Management of $H$. pylori infections has posed an economic burden on healthcare systems all over the world. It is becoming more challenging due to the emergence of antimicrobial resistance. The rate of resistance to levofloxacin, metronidazole, and clarithromycin have reached $15 \%$ in over 66,000 H. pylori isolates, according to a meta-analysis systematic study conducted in 2018 [8]. Clarithromycin resistant $H$. pylori is classified, by the World Health Organization, as a high priority pathogen for the development of new drugs [9].

The wide spread bacterial resistance, with the burden it poses on healthcare providers, highlights the concept of drug repurposing as a strategy to identify new uses for pre-existing drugs [10]. Anthelmintic, anti-inflammatory, anti-cancer, anti-psychotic drugs, and statins have been confirmed to possess anti-bacterial action; this is an approach that can save time, cost, and effort, as the safety and the pharmacokinetics properties of these agents are already documented [11]. In addition, novel approaches for antimicrobial drug discovery are now ongoing, based on genomics, proteomics, metabolic pathway analysis, essential gene analysis, and reverse docking $[12,13]$. They depend mainly on mining the genome/proteome sequence of the pathogen using many of the available bioinformatic tools, through different subtractive channels, such as similarity to human proteome, essentiality to the pathogen, and sub-cellular localization prediction to identify potential targets [14].

In silico subtractive approaches, besides being time saving, are cost effective in drug research and development stages [15]. These approaches were used to identify potential drug targets in many pathogens, including Acinetobacter baumannii, Burkholderia pseudomallei, Mycobacterium avium, Neisseria meningitides, Pseudomonas aeruginosa, Staphylococcus saprophyticus, and Streptococcus pneumoniae [16-22]. Similarly, several potential drug targets in H. pylori were also identified [12,23-26]; however, none of these studies predicted possible drug binding ligands, except for a study that proceeded to druggability analysis [27].

In our study, subtractive proteomics approaches were used to identify putative drug targets in H. pylori, through mining different available databases using strict inclusion and exclusion criteria, to yield potential host-safe drug targets. These targets are non-homologous to human, essential for the survival of $H$. pylori, cytoplasmic, less prevalent in common organisms of gut flora, and can act as broad-spectrum drug targets. Drugbank was searched for the possible repurposing of available non-antibiotic drugs as binding ligands. We were able to identify 17 protein targets with 42 binding ligands available at the drugbank.

\section{Results}

Three approaches were used to search the proteome of $H$. pylori for druggable targets. The analyzed protein pools were chokepoint proteins, metabolic pathway proteins or essential proteins. They were further subjected to different analysis steps, in each approach, to determine the druggable targets (Figure 1). 


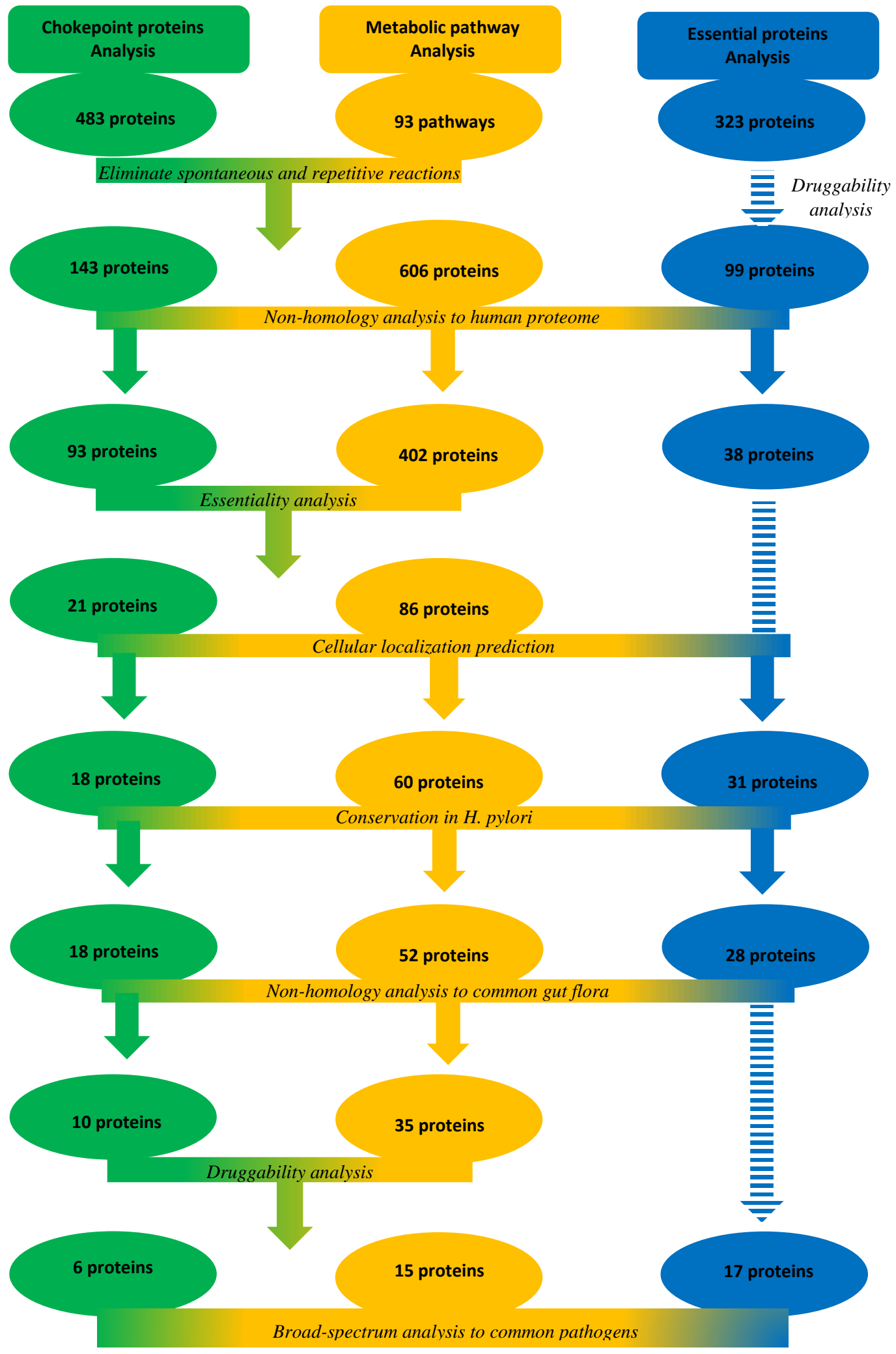

Figure 1. The three subtractive proteomics approaches used to identify potential drug targets in H. pylori proteome and their outcomes. 


\subsection{Chokepoint Proteins Analysis}

A Chokepoint reaction is either a unique consumer or producer of a metabolite and is regarded as a good drug target [28]. Searching the chokepoint reactions of the H. pylori ATCC 43504 strain in the BIOCYC database, after the exclusion of proteins found in humans and reactions that are catalyzed by more than one enzyme, resulted in 483 chokepoint reactions: 222 reactions on the consuming side and 261 reactions on the producing side. Upon analyzing these reactions, spontaneous and repeated reactions, along with those which had no identifiable enzymes in the database, were excluded, leaving 103 and 120 reactions in the consuming and producing sides, respectively. Eighty reactions were chokepoints on both sides, and the net yield was 143 proteins.

Proteins having significant similarity with human proteome $(n=50)$, identified by the National Center for Biotechnology Information (NCBI) BLASTp tool, were excluded. This resulted in 93 non-homologous targets. When these targets were searched for in the database of essential genes (DEG), only 21 proteins with percentage identity $>95$ were found to be essential for H. pylori. Prediction of the localization of these essential proteins, using the PSORTb cellular prediction tool, resulted in the exclusion of three outer membrane-proteins. All the remaining cytoplasmic proteins $(n=18)$ were checked for conservation in H. pylori strains, available at the NCBI database (Table S1), where all the tested proteins were conserved with significant similarity of $>200$ alignment scores. When these proteins were checked for homology to the proteome of common gut flora organisms, retrieved from a similar in silico study [29], eight proteins had significant similarity with an alignment score $>200$ and were, therefore, excluded from the analysis (Table S2).

Non-antibiotic binding ligands for the remaining 10 proteins were searched for at the drugbank [30]; only six proteins had potential binding ligands, and they included: 3-dehydroquinate dehydratase (AroQ), carboxy-S-adenosyl-L-methionine synthase (CmoA), 4-hydroxy-tetrahydrodipicolinate reductase (DapB), D-alanine-D-alanine ligase (Ddl), geranyl diphosphate synthase (IspA), and riboflavin synthase (RibC), as listed in Table 1. 
Table 1. Characteristics of H. pylori protein targets retrieved from chokepoint proteins, metabolic pathways and essential proteins subtractive approaches.

\begin{tabular}{|c|c|c|c|c|c|c|}
\hline Target & Protein Name & App & Pathway & $\begin{array}{c}\text { Similarity to } \\
\text { Common Pathogen }\end{array}$ & Possible Ligands & $\begin{array}{c}\text { Ligand Drugbank } \\
\text { Accession Number }\end{array}$ \\
\hline \multirow{3}{*}{ AroE } & \multirow{3}{*}{ Shikimate dehydrogenase } & \multirow{3}{*}{$\begin{array}{l}\text { PW } \\
\text { EP }\end{array}$} & \multirow{3}{*}{$\begin{array}{l}\text { Phenylalanine, tyrosine, and } \\
\text { tryptophan biosynthesis }\end{array}$} & \multirow{3}{*}{$\begin{array}{l}\text { Mostly } \\
80-200\end{array}$} & 1,4-Dithiothreitol & DB04447 \\
\hline & & & & & $\begin{array}{l}\text { Nicotinamide adenine dinucleotide } \\
\text { phosphate }\end{array}$ & DB03461 \\
\hline & & & & & 2'-Monophosphoadenosine-5'-diphosphate & DB02363 \\
\hline \multirow{8}{*}{ AroQ } & \multirow{8}{*}{ 3-dehydroquinate dehydratase } & \multirow{8}{*}{$\begin{array}{c}\text { CP } \\
\text { PW } \\
\text { EP }\end{array}$} & \multirow{8}{*}{$\begin{array}{l}\text { Phenylalanine, tyrosine, and } \\
\text { tryptophan biosynthesis }\end{array}$} & \multirow{8}{*}{$\begin{array}{l}\text { Mostly } \\
80-200\end{array}$} & 3-Dehydroquinic Acid & DB03868 \\
\hline & & & & & $\begin{array}{l}\text { N-(1,4-dihydro-5H-tetrazol-5-ylidene)-9-oxo- } \\
\text { 9H-xanthene-2-sulfonamide }\end{array}$ & DB04698 \\
\hline & & & & & 2,3-Anhydro-quinic acid & DB02801 \\
\hline & & & & & 3-Hydroxyimino quinic acid & DB03739 \\
\hline & & & & & 2-Anhydro-3-fluoro-quinic acid & DB02786 \\
\hline & & & & & 3-Dehydroshikimate & DB04347 \\
\hline & & & & & $\begin{array}{l}\text { 1,3,4-Trihydroxy-5-(3-phenoxypropyl)- } \\
\text { cyclohexane-1-carboxylic acid }\end{array}$ & DB04656 \\
\hline & & & & & $\begin{array}{l}\text { (1s,4s,5s)-1,4,5-Trihydroxy-3-[3-(phenylthio) } \\
\text { phenyl]cyclohex-2-ene-1-carboxylic acid }\end{array}$ & DB08485 \\
\hline \multirow{8}{*}{ CheY } & \multirow{8}{*}{ chemotaxis protein } & \multirow{8}{*}{$\begin{array}{l}\text { PW } \\
\text { EP }\end{array}$} & \multirow{8}{*}{$\begin{array}{l}\text { Two-component system and } \\
\text { bacterial chemotaxis }\end{array}$} & \multirow{8}{*}{$>200$} & S-Methyl Phosphocysteine & DB02461 \\
\hline & & & & & (S)-Aspartimide & DB03487 \\
\hline & & & & & Aspartate Beryllium Trifluoride & DB04156 \\
\hline & & & & & Adenosine-5'-Rp-Alpha-Thio-Triphosphate & DB02355 \\
\hline & & & & & $\begin{array}{l}\text { alpha,beta-Methyleneadenosine } \\
5^{\prime} \text {-triphosphate }\end{array}$ & DB02596 \\
\hline & & & & & 2-Hydroxyestradiol & DB07706 \\
\hline & & & & & Guanosine-5'-Monophosphate & DB01972 \\
\hline & & & & & Phosphoaspartate & DB01857 \\
\hline $\mathrm{CmoA}$ & $\begin{array}{l}\text { Carboxy-S-adenosyl-L-methionine } \\
\text { synthase }\end{array}$ & $\begin{array}{l}\mathrm{CP} \\
\mathrm{EP}\end{array}$ & $\begin{array}{l}\text { 5-(methoxycarbonylmethoxy)uridine } \\
\text { biosynthesis }\end{array}$ & $>200$ & S-Adenosyl-L-Homoselenocysteine & DB03423 \\
\hline
\end{tabular}


Table 1. Cont

\begin{tabular}{|c|c|c|c|c|c|c|}
\hline Target & Protein Name & App & Pathway & $\begin{array}{l}\text { Similarity to } \\
\text { Common Pathogen }\end{array}$ & Possible Ligands & $\begin{array}{l}\text { Ligand Drugbank } \\
\text { Accession Number }\end{array}$ \\
\hline \multirow{2}{*}{ DapB } & \multirow{2}{*}{$\begin{array}{l}\text { 4-hydroxy-tetrahydrodipicolinate } \\
\text { reductase }\end{array}$} & \multirow{2}{*}{$\begin{array}{l}\mathrm{CP} \\
\mathrm{PW} \\
\mathrm{EP}\end{array}$} & \multirow{2}{*}{ Lysine biosynthesis } & \multirow{2}{*}{$>200$} & 3-Acetylpyridine Adenine Dinucleotide & DB03363 \\
\hline & & & & & Dipicolinic acid & DB04267 \\
\hline Ddl & D-alanine-D-alanine ligase & $\begin{array}{l}\mathrm{CP} \\
\mathrm{PW} \\
\mathrm{EP}\end{array}$ & $\begin{array}{l}\text { D-alanine metabolism and } \\
\text { Peptidoglycan biosynthesis }\end{array}$ & $>200$ & $\begin{array}{l}\text { 3-Chloro-2,2-dimethyl-n-[4- } \\
\text { (trifluoromethyl)phenyl]propanamide }\end{array}$ & DB07805 \\
\hline DnaN & DNA polymerase III subunit $\beta$ & $\begin{array}{l}\mathrm{PW} \\
\mathrm{EP}\end{array}$ & $\begin{array}{l}\text { DNA replication, Mismatch } \\
\text { repair, and Homologous } \\
\text { recombination }\end{array}$ & $>200$ & $\begin{array}{l}\text { [(5R)-5-(2,3-dibromo-5-ethoxy-4-hydroxybenzyl)-4- } \\
\text { oxo-2-thioxo-1,3-thiazolidin-3-yl]acetic acid }\end{array}$ & 4- $\quad$ DB06998 \\
\hline \multirow{5}{*}{ HP0405 } & \multirow{5}{*}{ Hypothetical protein 0405} & \multirow{5}{*}{ EP } & \multirow{5}{*}{ NA } & \multirow{5}{*}{$>200$} & Selenocysteine & DB02345 \\
\hline & & & & & S-Mercaptocysteine & DB02761 \\
\hline & & & & & S-Selanyl Cysteine & DB03049 \\
\hline & & & & & L-2-amino-3-butynoic acid & DB04217 \\
\hline & & & & & $\begin{array}{l}\text { 3'-O-N-Octanoyl-a-D-Glucopyranosyl- } \\
\text { B-D-Fructofuranoside }\end{array}$ & DB02346 \\
\hline \multirow{3}{*}{ IspA } & \multirow{3}{*}{ Geranyl diphosphate synthase } & \multirow{3}{*}{$\begin{array}{l}\mathrm{CP} \\
\mathrm{PW} \\
\mathrm{EP}\end{array}$} & \multirow{3}{*}{$\begin{array}{l}\text { Terpenoid backbone } \\
\text { biosynthesis }\end{array}$} & \multirow{3}{*}{$>200$} & Pyrophosphoric acid & DB04160 \\
\hline & & & & & Isopentyl Pyrophosphate & DB02508 \\
\hline & & & & & Dimethylallyl S-Thiolodiphosphate & DB02270 \\
\hline $\begin{array}{l}\text { LacA/ } \\
\text { Rpi }\end{array}$ & Ribose-5-phosphate isomerase B & $\begin{array}{l}\text { PW } \\
\mathrm{EP}\end{array}$ & $\begin{array}{l}\text { Pentose phosphate pathway, } \\
\text { Fructose and mannose } \\
\text { metabolism }\end{array}$ & $80-200$ & 2'-Monophosphoadenosine-5'-Diphosphate & DB02363 \\
\hline \multirow{3}{*}{ LpxA } & \multirow{3}{*}{$\begin{array}{c}\text { Acyl-[acyl-carrier-protein]-UDP } \\
\text {-N-acetylglucosamine } \\
\text { O-acyltransferase }\end{array}$} & \multirow{3}{*}{$\begin{array}{l}\mathrm{PW} \\
\mathrm{EP}\end{array}$} & \multirow{3}{*}{$\begin{array}{l}\text { Lipopolysaccharide } \\
\text { biosynthesis }\end{array}$} & \multirow{3}{*}{$>200$} & D-tartaric acid & DB01694 \\
\hline & & & & & $\begin{array}{l}\text { 2-Hydroxymethyl-6-octylsulfanyl-tetrahydro- } \\
\text { pyran-3,4,5-triol }\end{array}$ & DB08558 \\
\hline & & & & & $\begin{array}{l}\text { 4-Chloro-N-(3-methoxypropyl)-N-[(3S)-1- } \\
\text { (2-phenylethyl)piperidin-3-yl]benzamide }\end{array}$ & DB08344 \\
\hline \multirow{2}{*}{ PanD } & \multirow{2}{*}{$\begin{array}{l}\text { Aspartate 1-decarboxylase } \\
\text { proenzyme }\end{array}$} & \multirow{2}{*}{$\begin{array}{l}\mathrm{PW} \\
\mathrm{EP}\end{array}$} & \multirow{2}{*}{$\beta$-alanine metabolism } & \multirow{2}{*}{$80-200$} & Malonic acid & DB02175 \\
\hline & & & & & S-oxy-L-cysteine & DB03382 \\
\hline
\end{tabular}


Table 1. Cont.

\begin{tabular}{|c|c|c|c|c|c|c|}
\hline Target & Protein Name & App & Pathway & $\begin{array}{c}\text { Similarity to } \\
\text { Common Pathogen }\end{array}$ & Possible Ligands & $\begin{array}{r}\text { Ligand Drugbank } \\
\text { Accession Number }\end{array}$ \\
\hline \multirow{3}{*}{ RibC } & \multirow{3}{*}{ Riboflavin synthase } & \multirow{3}{*}{$\begin{array}{c}\text { CP } \\
\text { PW } \\
\text { EP }\end{array}$} & \multirow{3}{*}{ Riboflavin metabolism } & \multirow{3}{*}{$>200$} & Citric acid & DB04272 \\
\hline & & & & & Flavin mononucleotide & DB03247 \\
\hline & & & & & Lumichrome & DB04345 \\
\hline RplE & 50 S ribosomal subunit L5 & $\begin{array}{l}\text { PW } \\
\text { EP }\end{array}$ & Ribosome & $>200$ & (S)-3-phenyllactic acid & DB02494 \\
\hline RpsF & $30 \mathrm{~S}$ ribosomal subunit $\mathrm{S} 6$ & $\begin{array}{l}\text { PW } \\
\text { EP }\end{array}$ & Ribosome & $80-200$ & $\begin{array}{l}\text { 2-Methylthio-n6-isopentenyl-adenosine- } \\
\text { 5'-monophosphate }\end{array}$ & DB08185 \\
\hline RpsJ & 30S ribosomal subunit $\mathrm{S} 10$ & $\begin{array}{l}\mathrm{PW} \\
\mathrm{EP}\end{array}$ & Ribosome & $80-200$ & $\begin{array}{l}\text { 2-Methylthio-n6-isopentenyl-adenosine- } \\
\text { 5'-monophosphate }\end{array}$ & DB08185 \\
\hline TrbB/VirB11_2 & Type IV secretion system ATPase & $\begin{array}{l}\text { PW } \\
\text { EP }\end{array}$ & $\begin{array}{c}\text { Bacterial secretion system } \\
\text { Epithelial cell signaling }\end{array}$ & Mostly 80-200 & 2'-Monophosphoadenosine-5'-Diphosphate & DB02363 \\
\hline
\end{tabular}

$\mathrm{App}=$ Approach; $\mathrm{CP}=$ Chokepoint proteins approach; $\mathrm{PW}=$ Metabolic pathway proteins approach; $\mathrm{EP}=$ Essential proteins approach. 


\subsection{Metabolic Pathway Analysis}

In this approach, the initial protein targets were those involved in the metabolic pathways of H. pylori. These pathways were retrieved from the Kyoto Encyclopedia of Genes and Genomes (KEGG) [31-33] database, where 93 pathways for H. pylori strain 26695 were available, comprising 1672 proteins. After the removal of repetitions and non-identifiable enzymes, only 606 proteins remained; 402 proteins showed no significant similarity when compared to human proteome at NCBI BLASTp (Table S3).

The human non-homologous proteins $(n=402)$ were checked in DEG for essentiality, where 86 proteins were essential for $H$. pylori. Sub-cellular localization prediction yielded 12 proteins with unknown localization, one periplasmic-, 13 cytoplasmic-membrane-, and 60 cytoplasmic-proteins. Among the cytoplasmic proteins, eight showed alignment scores below 200 with other H. pylori strains available at the NCBI database, and were, therefore, excluded. Upon comparing the remaining 52 proteins with common gut flora: 17 proteins were excluded because they had $>200$ alignment scores; seven proteins showed no significant similarity to any of the compared gut flora organisms, and one protein showed only 40-50 score; 27 proteins had similarity scores between 50 and 200 (Table S3).

Only 16 protein targets, out of the selected 35 proteins, were druggable (Table S3; Figure 1). RplV was excluded, as lefamulin and quinupristin antibiotics were its binding ligands. These targets included all proteins retrieved from chokepoint analysis (except $\mathrm{CmoA}$ ), besides shikimate dehydrogenase (AroE), chemotaxis protein $Y(\mathrm{CheY})$, DNA polymerase III subunit $\beta$ (DnaN), ribose-5-phosphate isomerase $B$ (LacA/Rpi), acyl- [acyl-carrier-protein]-UDP-N-acetylglucosamine O-acyltransferase (LpxA), aspartate 1-decarboxylase proenzyme (PanD), 50S ribosomal subunit L5 (RplE), 30S ribosomal subunit S6 (RpsF), 30S ribosomal subunit S10 (RpsJ), and type IV secretion system ATPase (TrbB/VirB11_2). They all had $>200$ alignment scores to common pathogens, except for PanD, LacA/Rpi, RpsF, and RpsJ, which had an alignment score $<200$ (Table 1). The general and related metabolic pathways of these targets are summarized in Figure 2.

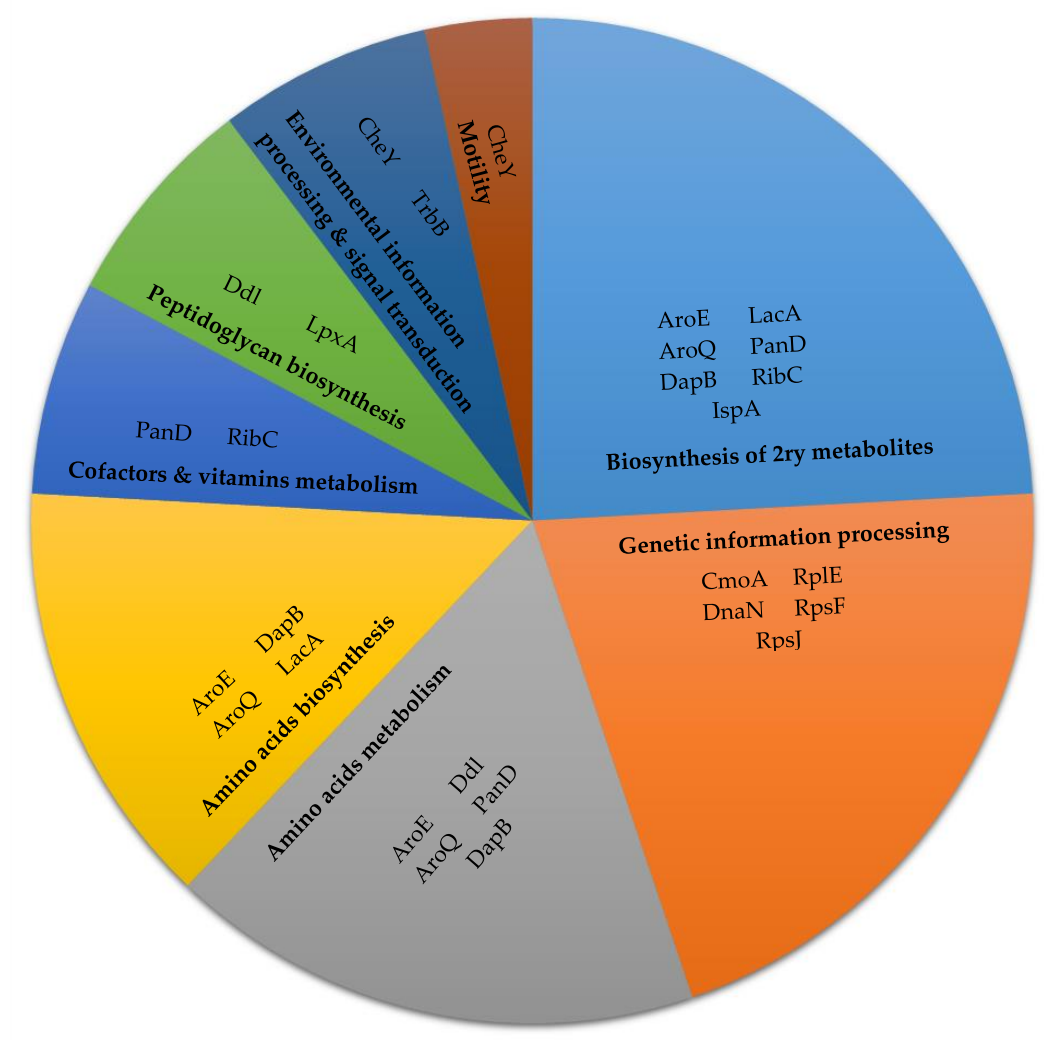

Figure 2. Pathways of targets retrieved from both chokepoint proteins analysis and metabolic pathway proteins analysis. 


\subsection{Essential Proteins Analysis}

Three hundred twenty-three essential proteins for H. pylori strain 26695 were retrieved from DEG. This was followed by searching the drugbank for possible binding ligands, where 100 proteins were druggable. After excluding RplV (having an antibiotic ligand) and 61 proteins that showed significant similarity to human proteome, 38 proteins were retrieved. Their sub-cellular localization was checked; one protein was periplasmic, one was an outer membrane protein, two had unknown localization prediction, three were cytoplasmic membrane proteins, and 31 were cytoplasmic proteins (Table S4).

The cytoplasmic proteins $(n=31)$ were checked for conservation in $H$. pylori strains available at NCBI, using NCBI BLASTp, where three proteins showed $<200$ alignment scores to other H. pylori strains and were, therefore, excluded. The remaining proteins $(n=28)$ were checked for non-homology to the proteome of common gut flora organisms, where 11 proteins had $>200$ alignment scores and were excluded (Table S4). The remaining seventeen targets included the targets retrieved from the other two approaches, besides the hypothetical protein HP0405 (Table 1; Figure 3), which had an alignment score $>200$ to common pathogens.

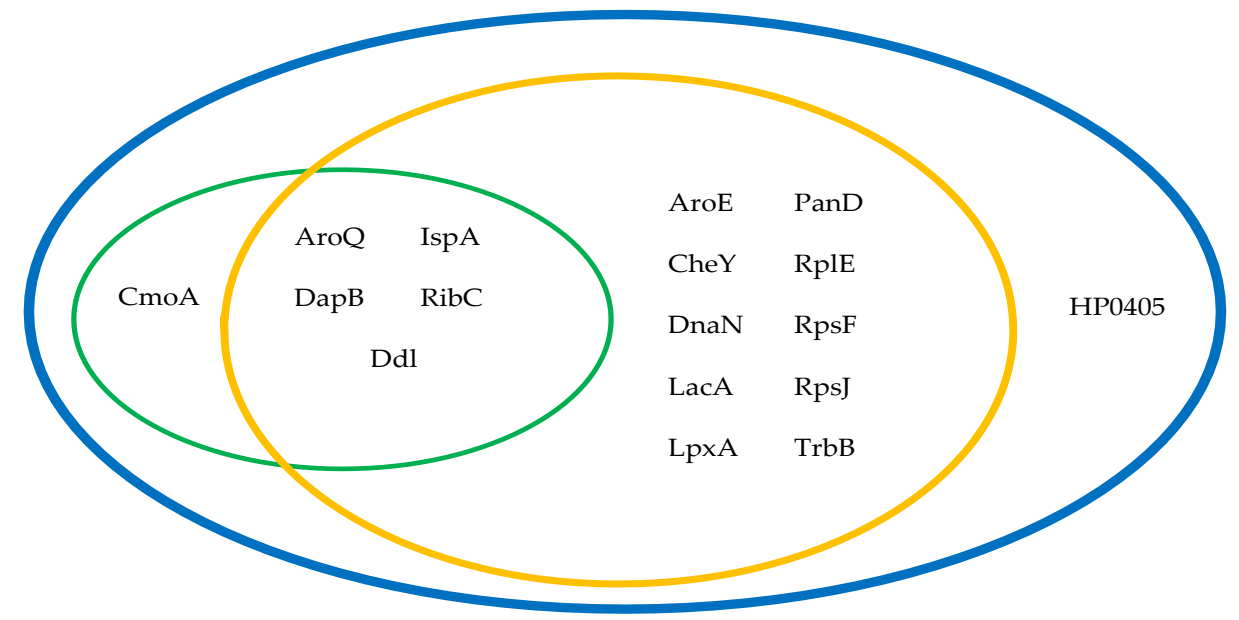

Figure 3. Protein targets retrieved from chokepoint proteins (green), metabolic pathway (orange), and essential proteins analysis (blue) approaches.

Our retrieved targets had 42 different potential binding ligands at the drugbank, after excluding repetitions and antibiotics in some targets. All ligands were classified as experimental small molecules, except for pyrophosphoric acid, citric acid, and flavin mononucleotide, which were approved small molecules. Some ligands can interact with multiple targets. 2'-monophosphoadenosine-5'-diphosphate can act as a binding ligand for AroE, LacA/Rpi, and TrbB/Vir11_2, while 2-methylthio-n6-isopentenyl-adenosine-5' -monophosphate can act on both RpsF and RpsJ. The retrieved ligands, their classes, current uses, and the expect value of the drugbank blast of the target proteins are summarized in Table S5.

\subsection{The In Vitro Anti-Helicobacter Activity of Selected Ligands}

Three ligands, citric acid, dipicolinic acid, and pyrophosphoric acid, were tested for their anti-helicobacter activity. Minimum inhibitory concentration (MIC) determination, by agar dilution and broth micro-dilution methods, was used to test the drug ligands against the H. pylori ATCC 43504 strain and a clinical H. pylori isolate. The three tested ligands were effective as anti-helicobacter agents. The MIC values for citric and dipicolinic acid, by both tested methods, were $1.5 \mathrm{mg} / \mathrm{mL}$ against the H. pylori ATCC 43504 strain and the H. pylori clinical isolate. The pyrophosphoric acid MIC was 3 and $2 \mathrm{mg} / \mathrm{mL}$ by agar dilution and broth micro-dilution methods, respectively, against the tested $H$. pylori isolates (Figure 4). 


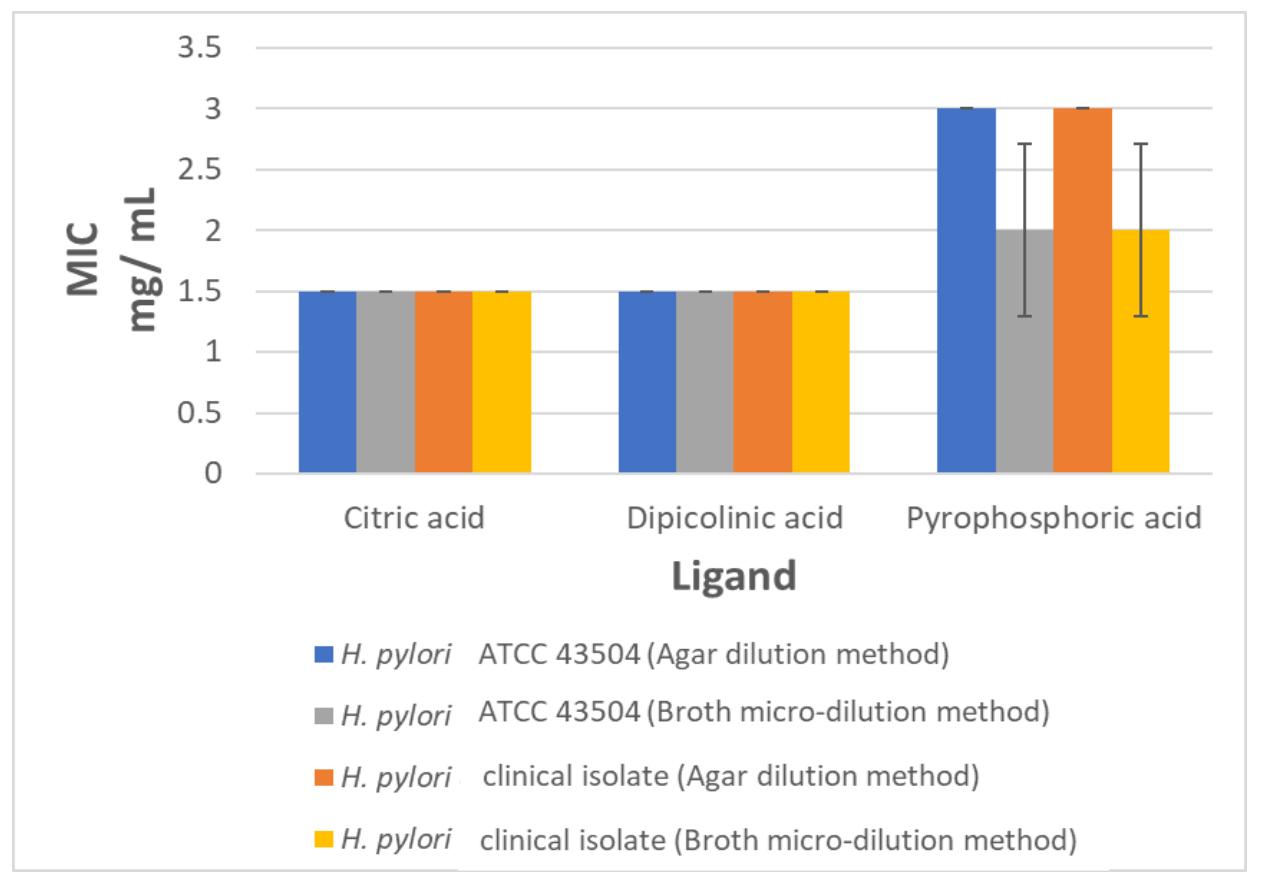

Figure 4. Minimum inhibitory concentration (MIC) of the tested ligands against tested H.pylori strains using agar dilution and broth micro-dilution methods. MIC values represent the mean of three experimental repliactes.

\section{Discussion}

Treatment of H. pylori infections is becoming more difficult with the reported increase in the rate of emergence of resistance to most of the available antibiotics and the scarce development of newer effective antimicrobials. Repurposing of non-antibiotic drugs, as antimicrobials, has gained renewed attention, saving time and cost required to design, synthesize, and test novel therapeutic compounds [11]. Three different in silico approaches were used to search for promising drug targets in $H$. pylori, all of which used almost the same tools, with the same parameters, but in a different order. The selected criteria aimed to ensure efficient druggable targets with minimum host side effects.

To avoid host toxicity, drug targets with similar counterparts in human should be excluded [14]. In all our studied approaches, non-homology to human proteome was tested with strict criteria: an expected threshold of 0.005 , although the default expected threshold was set to 10 at NCBI BLASTp, and a deep scoring matrix "BLOSUM62" targeted alignments with even 20-30\% identity [34]. In contrast to studies that accept targets with $<100$ scores [35-37], we excluded any targets that showed even minor significant similarity (with scores $<40$ ). All the selected drug targets were essential proteins, where essential genes/proteins are indispensable for the life of organisms, and therefore, can act as potential drug targets, especially if they are conserved [38]. Proteins with $>95 \%$ identity to H. pylori essential proteins were selected based on a 0.00001 expected threshold and "BLOSUM62" matrix. Furthermore, the selected essential proteins were blasted against $H$. pylori strains with the highest possible alignment scores; this confirmed conservation in H. pylori. Also, being conserved across common pathogenic species allows broad spectrum targeting. Our targets showed significant similarity with the proteome of 228 common pathogenic organisms retrieved from a similar in silico study [29].

All targets that lacked significant similarity to the common gut flora organisms (AtpF, AtpH, FolB, NuoF, HP0276, HP0439, and HP1247) were non-druggable, thus hindering the repurposing of available agents for their inhibition. However, these proteins represent promising targets for the design of new anti-helicobacter agents. FolB, involved in folate biosynthesis, was druggable in a similar in silico study as a potential drug target for Klebsiella pneumoniae [39]. In our study, the cut-off value of alignment similarity scores was reset to not exceed 200, in order to minimize the disruption of the host's gut 
flora as much as possible, and the subsequent adverse effects related to their possible inhibition [29]. Determination of the sub-cellular localization of candidate proteins is an essential tool for identifying effective drug targets and vaccine candidates in bioinformatics studies. Cytoplasmic proteins are favorable drug targets [40]. Targets with only antibiotic ligands were also excluded, to avoid resistance to the currently in use antibiotics and to ensure novelty of the ligands.

In our study, 6, 15, and 17 targets were retrieved from chokepoint proteins, metabolic pathway proteins, and essential proteins analysis approaches, respectively. All essential proteins approach targets were also retrieved by the other two approaches, as they had to pass through DEG at a certain point of the analysis. Therefore, the essential proteins analysis approach is the best approach in terms of time, effort, and ease of analysis; it was previously used in the identification of potential drug targets in Burkholderia pseudomallei [16], and to identify potential membrane proteins as vaccine targets in H. pylori [23].

Similar to our study, KEGG and DEG databases were also used to identify drug targets in H. pylori strain HPAG1 [26]. CheY and Ddl were common drug targets; however, their other detected targets did not make it to our final list. This is due to having a lower essential percentage identity cut-off set value (<95\%, e.g., $\mathrm{KdsA}, \mathrm{GlmU}$, and $\operatorname{TrpA}$ ), not being cytoplasmic (e.g., RfaC, and MurF), having a high similarity score with common gut flora (>200, e.g., LpxD, and LpxC) and being non-druggable (e.g., WaaA, and GmhB). Neelapu and co-workers used a different set of computational resources to identify drug targets in H. pylori [24]; most of their protein targets were excluded from our analysis for not achieving the cut-off percentage identity at DEG (e.g., RpmG, MoaD, ThiM, and ThiE), not being cytoplasmic (e.g., DppC, and HP0164), or not being druggable (e.g., Hup).

Five protein targets, AroQ, DapB, Ddl, IspA, and RibC were commonly retrieved from our three approaches. Both AroQ and AroE (retrieved from metabolic pathway proteins and essential proteins analysis approaches) are involved in the chorismate synthesis, which is the precursor of folic acid and aromatic amino acids (phenylalanine, tyrosine, and tryptophan) that take part in protein and nucleic acid biosynthesis. Inhibition of folate biosynthesis is known to exert an anti-helicobacter activity [41,42]. DapB is involved in lysine biosynthesis via diaminopimelate, which are compounds used by bacteria to link peptidoglycan covalently to their cell wall. Ddl, with the aid of alanine racemase (Alr), builds up D-alanyl-D-alanine for peptidoglycan biosynthesis. IspA catalyses two sequential reactions in the isoprenoid or terpenoids biosynthesis, which are required in cell wall synthesis. Targeting cell wall biosynthesis by both amoxicillin and cephalosporins is already being used in the treatment of H. pylori infections [43]; however, these antibiotics have different enzymatic drug targets. RibC is involved in riboflavin biosynthesis, which is the precursor of the coenzymes required in redox reactions. Some antibiotics (e.g., ampicillin, gentamicin, and norfloxacin) can alter the redox homeostasis of bacterial cells, to pose an oxidative stress that contributes, ultimately, to cell death [44].

Targets retrieved from the metabolic pathway analysis were similar to those identified from chokepoint protein analysis, except for $\mathrm{CmoA}$, which was not identified by the metabolic pathway analysis. When searching for a CmoA sequence at the KEGG database, it was not present in KEGG pathways, but was present in KEGG brite. The brite database is an ontology database that has been introduced to expand the coverage of genes for KEGG mapping [32]. CmoA converts S-adenosyl-L-methionine to carboxy-S-adenosyl-L-methionine, which is involved in the maturation of bacterial tRNAs [45]. Aminoglycosides are known to interfere with the tRNA maturation process [46], where some members of this class (gentamicin and netilmicin) have promising anti-helicobacter activity [47].

In addition, ten targets, AroE, CheY, PanD, TrbB/VirB11_2, DnaN, RplE, RpsF, RpsJ, LacA/Rpi, and LpxA, were retrieved from both metabolic pathway proteins analysis, and essential proteins analysis approaches. Chemotaxis protein, $\mathrm{CheY}$, is involved in the signal transmission from chemoreceptors to the flagellar motors. Chemotaxis and motility are essential for both the survival and colonization of H. pylori, where impaired chemotactic responses to gastric mucin makes the pathogen move in a linear rather than swarming and tumbling motion, which can end up in the failure to evade gastric 
acidity, colonization, and allow pathogen removal by gastric flow [48]. PanD catalyzes the conversion of L-aspartate into $\beta$-alanine, which is further required for pantothenate biosynthesis, the precursor of coenzyme A. Disruption of the genes/enzymes in CoA biosynthesis can lead to lethal phenotypes [49]; also, several natural and synthetic pantothenic acid analogues possess antibacterial activity [50]. TrbB/VirB11_2 is essential for gastric colonization and represents a component of the type IV secretion system, which is required for the oncogenic CagA transport into the targeted epithelial cells [51,52]. Pathogenesis, severity of infection, malignancies, and survival in acid moiety are significantly related to the presence of a cag pathogenicity island (cag PAI) and a type IV secretion system, compared to cag PAI-negative strains [53-55]. Compounds with anti-virulence activity are considered unusual promising agents that help the immune system to overcome the infectious agents without development of resistance [56].

The DNA polymerase III $\beta$ subunit (DnaN) and the ribosomal subunits (RplE, RpsF, and RpsJ) are involved in genetic information processing. DnaN functions as a sliding clamp during DNA replication, and is essential for cell viability, therefore representing a promising target for antibacterial drugs. The binding sites and sequences of bacterial and eukaryotes sliding clamps are different, allowing for specific targeting [57]. Our criteria allowed only for the selection of conserved targets among the tested $H$. pylori strains with an alignment score $>200$, and exclusion of any targets with even slight similarity to the human proteome. The non-steroidal anti-inflammatory drug, diflunisal, exerts an anti-helicobacter activity by inhibiting the $\beta$-clamp function [58]. Also, targeting DnaN was efficient in tuberculosis therapy [59]. Inhibition of ribosomal subunits interferes with protein synthesis, which is already targeted by many antibiotics, including clindamycin, puromycin, and tetracycline [60]. LacA/Rpi is involved in lipid biosynthesis, while LpxA, along with other proteins, is involved in lipopolysaccharide biosynthesis. Inhibition of lipid biosynthesis is a drug target in many bacterial species [61]. HP0405 was only identified by using the essential protein analysis approach; it is an NifS-like hypothetical protein of an unknown function [62].

Many binding ligands, for these targets, were identifiable in drugbank. The drugbank blast results for our protein targets showed a low expected threshold value, indicating very low chance of error hits and potential specific binding to the ligands. Some of our ligands are small organic acids with documented safety and antibacterial activity, such as (S)-3-phenyllactic acid [63], citric acid [64], malonic acid [65], dipicolinic acid [66], and D-tartaric acid [67,68]. Organic acids are used as food additives and preservatives $[69,70]$, and have also shown anti-helicobacter activity as components in probiotics and natural products [71-73].

Nicotinamide adenine dinucleotide phosphate, an AroE binding ligand, and guanosine- $5^{\prime}$-monophosphate, a CheY binding ligand, possess $\beta$-lactamase inhibition activity $[74,75]$. Both quinic and shikimic organic acid exert an inhibitory effect on Staphylococcus aureus [76]; we detected some of their derivatives (3-dehydroquinic acid; 2,3-anhydro-quinic acid; 3-hydroxyimino quinic acid; 2-anhydro-3-fluoro-quinic acid; 3-dehydroshikimate) as AroQ binding ligands. Most of the AroE, AroQ, CheY, DapB, Ddl, LpxA, and PanD detected binding ligands were previously reported, in a similar in silico study, to bind to the same targets in Campylobacter jejuni [77].

Searching the protein data bank revealed that seven out of the 17 protein targets (AroE, AroQ, CheY, Ddl, DnaN, LpxA, and PanD) have their crystalline 3D structure available, facilitating performing a further docking study to confirm the inhibitory role of their ligands.

We further confirmed our in silico study by testing three drug ligands, citric, dipicolinic, and pyrophosphoric acid, for their anti-helicobacter activity. The drugs were chosen based on their possible activity against three of the common protein targets, retrieved by all three approaches (RibC, DapB, and IspA). The MIC values for citric, dipicolinic, and pyrophosphoric acid ranged from 1.5-2.5 $\mathrm{mg} / \mathrm{mL}$. The MIC detected by the agar dilution and broth micro-dilution methods were comparable. The anti-helicobacter activity of citric acid was previously reported [78]. However, this is the first report of the anti-helicobacter activity of dipicolinic, and pyrophosphoric acid. 


\section{Materials and Methods}

\subsection{Analysis of Chokepoint Proteins and Metabolic Pathway Proteins}

The initial protein pools used for these two approaches were retrieved from either the BIOCYC chokepoint reactions database [79], or KEGG pathways database [31-33]. This was followed by different subtractive proteomics steps to reach efficient druggable targets. A schematic flow of these two approaches is illustrated in Figure 5.

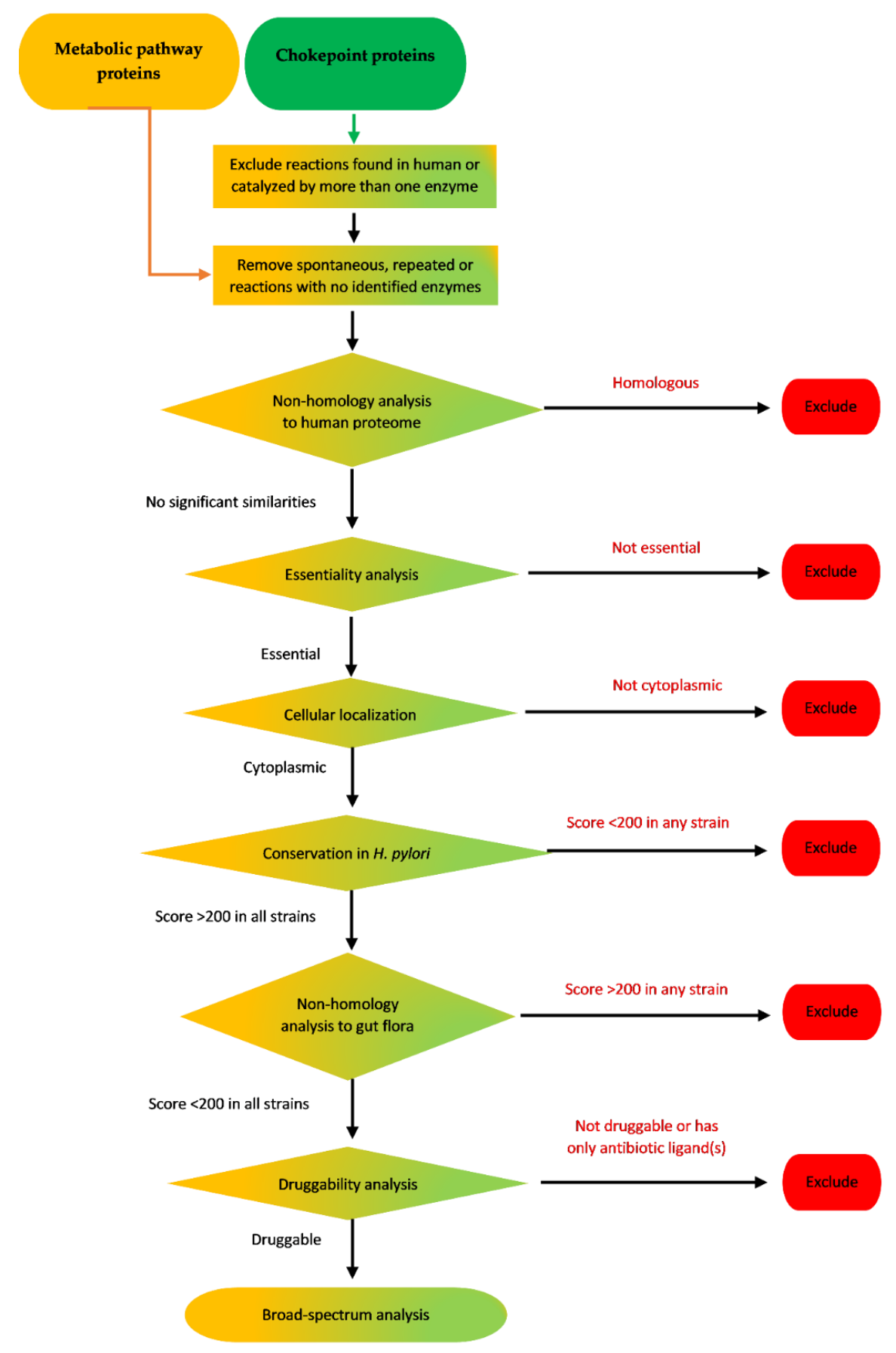

Figure 5. Schematic flow chart of chokepoint proteins analysis and metabolic pathway proteins analysis of $H$. pylori proteome. 


\subsubsection{Retrieval of Chokepoint Proteins of H. pylori}

Chokepoint reactions of $H$. pylori ATCC 43504 were retrieved from the BIOCYC collection database [79], available at http://biocyc.org/chokepoint-form.shtml, with the following criteria: exclusion of reactions found in humans, exclusion of reactions catalyzed by more than one enzyme, and then inclusion of all reactions. Resulted reactions, from both consuming and producing sides, were checked to remove spontaneous reactions, reactions by enzymes that have not been identified by this database, and repeated reactions on both sides.

\subsubsection{Retrieval of Proteins Involved in H. pylori Metabolic Pathways}

All the metabolic pathways of H. pylori strain 26695 (ATCC 700392) were retrieved from the KEGG database [31-33], available at https://www.genome.jp/kegg/pathway.html. Repeated reactions from the different pathways were removed, along with spontaneous reactions or those with no identifiable enzymes. The search tool BLAST FASTA (prot query vs. prot db), available at https: //www.genome.jp/tools/fasta/, was used whenever needed to find a particular protein at KEGG database.

\subsubsection{Non-Homology Analysis to Human Proteins}

Non-homology analysis of the retrieved targets was performed using the NCBI BLASTp tool (protein-protein blast) [80], available at https://blast.ncbi.nlm.nih.gov, with the non-redundant protein sequences (nr) database against Homo sapiens (taxid:9606), and with algorithm general parameters as an expect threshold of 0.005 and scoring parameters as matrix BLOSUM62. Any protein with significant alignments (even if $<40$ ) was excluded.

\subsubsection{Essentiality Analysis}

Protein targets that were not homologous to human proteome were searched for essentiality in H. pylori using DEG $[38,81,82]$, version 15.2, available at http://www.essentialgene.org, with parameters set as an expected threshold of 0.00001 and matrix BLOSUM62. Any result with a percentage identity $>95$ was accepted.

\subsubsection{Prediction of Sub-Cellular Localization}

The sub-cellular localization of the retrieved essential proteins was predicted to select intracellular cytoplasmic proteins using the cellular localization prediction tool PSORTb version 3.0.2 [83], available at http://www.psort.org/psortb/. Final prediction as "cytoplasmic" with a cut-off score of $>8.5$ was accepted. Proteins with localizations other than cytoplasmic were excluded.

\subsubsection{Conservation in H. pylori}

The conservation of cytoplasmic targets was tested in all available $H$. pylori strains at the NCBI database (Table S1) using the NCBI BLASTp tool, with an expected threshold of 0.0001. Only targets that were conserved with > 200 alignment scores, in all tested H. pylori strains, were used in subsequent steps.

\subsubsection{Non-Homology to Proteome of Common Gut Flora Organisms}

Protein targets were compared to the proteomes of common organisms known to naturally inhabit the gut of healthy individuals, according to Raman and colleagues [29], using the NCBI BLASTp tool with an expected threshold of 0.0001 .

\subsubsection{Druggability Analysis}

Targets were searched for at Drugbank collection version 5.1.6 [30], available at http://www. drugbank.ca/, to find non-antibiotic ligands using the default BLAST parameters, with an expected threshold of 0.00001 and with the drug type filter set to include all drug types. 


\subsubsection{Checking for Broad-Spectrum Targeting}

Druggable targets were compared to the proteomes of common pathogenic organisms [29] using NCBI the BLASTp tool with an expect threshold of 0.0001 and matrix BLOSUM62.

\subsection{Essential Proteins Analysis}

A similar approach to the aforementioned approaches, but with a different flow pattern, was tested (Figure 6). All search tools, parameters, and thresholds were like those described in the previous two approaches.

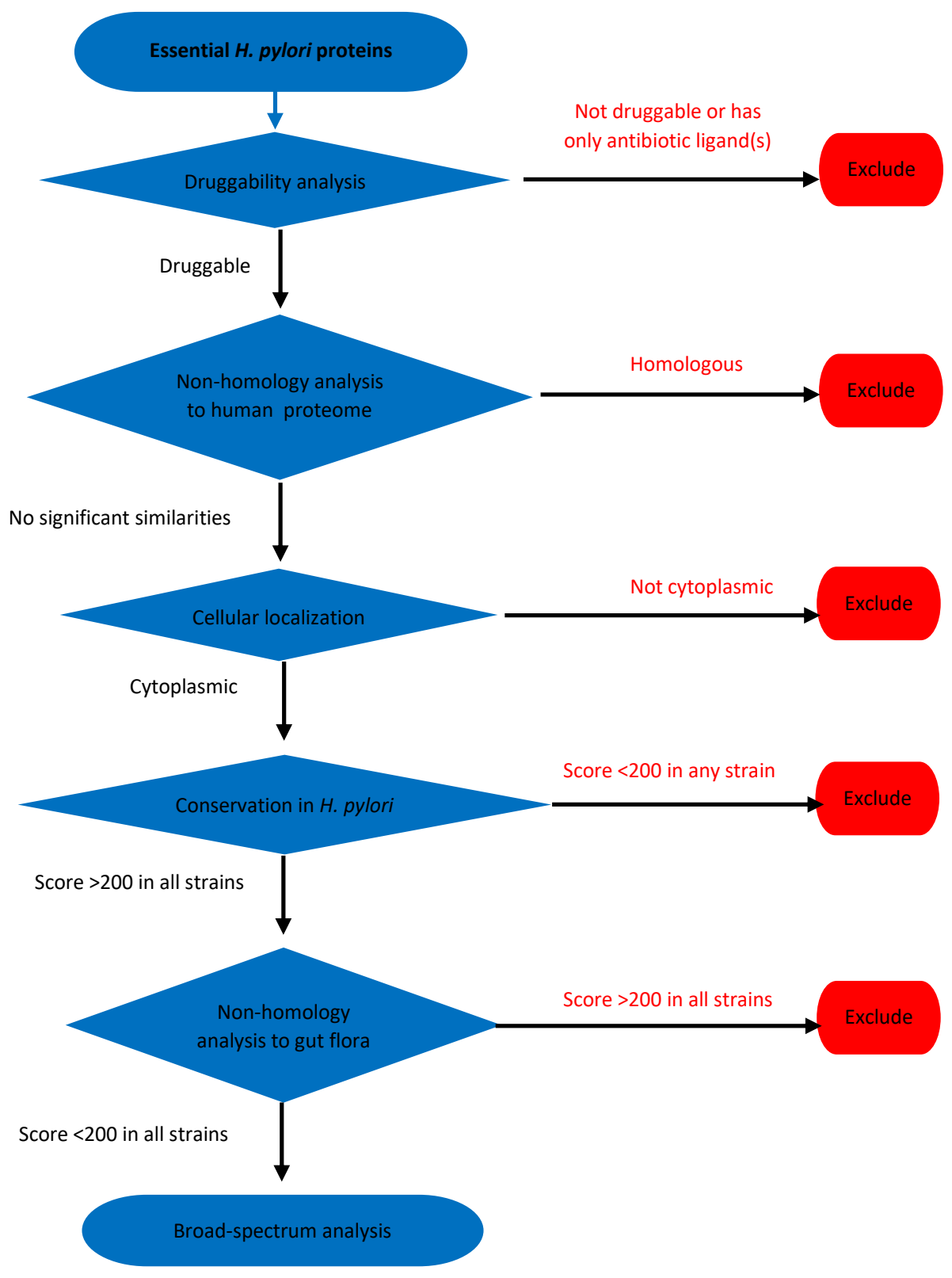

Figure 6. Schematic flow chart of essential proteins analysis of H. pylori proteome.

\subsection{Determination of MIC}

The bacterial strains used in the study included H. pylori ATCC 43504, and a clinical H. pylori isolate obtained from the culture collection of the department of clinical pathology, Faculty of Medicine (Kasr El-Aini), Cairo university, Cairo, Egypt. Isolates were subcultured on Muller-Hinton agar (MAST, 
Bootle, UK), supplemented with 5\% sheep blood and DENT supplement (Oxoid, Basingstoke, UK), and incubated at $37^{\circ} \mathrm{C}$ for $72 \mathrm{~h}$ under microaerophilic conditions $\left(5 \% \mathrm{O}_{2}, 10 \% \mathrm{CO}_{2}\right.$, and $85 \% \mathrm{~N}_{2}$ at $95 \%$ humidity) using CamyGen paper sachets (Oxoid, Basingstoke, UK) [84]. Colonies were suspended in saline to reach an optical density equivalent to McFarland 2.0 turbidity standard (approximately $\left.1 \times 10^{7}-1 \times 10^{8} \mathrm{CFU} / \mathrm{mL}\right)[85]$.

Citric acid (Loba Chemie, Mumbai, India), dipicolinic acid (Alfa Aesar, Kandel, Germany), and pyrophosphoric acid (Sigma Aldrich, Steinheim, Germany) solutions in distilled water were freshly prepared and sterilized by membrane filtration using a $0.22 \mu \mathrm{m}$ pore-size syringe filter (StarTech, Northampton, UK). The final tested concentrations ranged from $0.19-6 \mathrm{mg} / \mathrm{mL}$. The MIC values were determined using the agar dilution and broth micro-dilution methods.

The agar dilution method was performed according to the Clinical and Laboratory institute CLSI guidelines. Briefly, $2 \mu \mathrm{L}$ inoculums (equivalent to $1 \times 10^{4} \mathrm{CFU} / \mathrm{spot}$ ) were delivered to the surface of plates of Muller-Hinton agar supplemented with 5\% sheep blood and containing the specified dilution of the ligand. Plates were incubated at $37{ }^{\circ} \mathrm{C}$ for $72 \mathrm{~h}$, under microaerophilic conditions. The experiment was done in triplicates. Inoculum was delivered to the surface of Muller-Hinton agar plates supplemented with 5\% sheep blood to act as growth control. The MIC value was the lowest concentration of the compound, completely inhibiting visible bacterial growth [85].

The broth micro-dilution method was performed, according to Piccolomini and colleagues [84], with minor modifications. Briefly, ligand solutions were diluted in Brucella broth (Conda, Madrid, Spain) supplemented with 10\% fetal bovine serum (Sigma-Aldrich, Steinheim, Germany) to get the specified concentrations. Each well contained $100 \mu \mathrm{L}$ of ligand-containing broth at the specified concentration. The adjusted inoculum $(10 \mu \mathrm{L})$ was added, so that each well contained $5 \times 10^{5} \mathrm{CFU} / \mathrm{mL}$, and the microtiter plates were incubated at $37^{\circ} \mathrm{C}$ for $72 \mathrm{~h}$ under microaerophilic conditions. The MIC was the lowest concentration that completely inhibited the visible growth of the tested organism.

\section{Conclusions}

Using subtractive proteomics approaches proved very efficient in saving time, money, and effort expended in the detection of novel drug targets and their potential inhibitors. This approach enabled us to identify 17 potential druggable targets in $H$. pylori, and the possible repurposing of available agents to inhibit these targets. This provides new hope for saving lives of those at high risk of infection with the carcinogenic $H$. pylori pathogen. This is a preliminary study; further testing is still required to confirm the potential use of these ligands in the treatment of H. pylori infections and the target specificity, as well as the safety and possible side effects.

Supplementary Materials: The following are available online at http://www.mdpi.com/2076-0817/9/9/747/s1, Table S1: Helicobacter pylori strains available at NCBI BLASTp database, Table S2: Characteristics of all chokepoint proteins of H. pylori ATCC 43504 strain from BIOCYC database, Table S3: Characteristics of all metabolic pathway proteins from KEGG database, Table S4: Characteristics of all essential proteins from DEG database, Table S5: Characteristics of the potential ligands retrieved from drugbank.

Author Contributions: Conceptualization, O.M.H., M.T.K. and M.A.R.; Data curation, K.A.I., O.M.H. and M.T.K.; Formal analysis, K.A.I., O.M.H. and M.T.K.; Investigation, K.A.I., O.M.H. and M.T.K.; Methodology, K.A.I.; Resources, K.A.I., O.M.H. and M.T.K.; Supervision, O.M.H., M.T.K., T.R.E. and M.A.R.; Validation, K.A.I., O.M.H. and M.T.K.; Writing—original draft, K.A.I.; Writing—review \& editing, O.M.H., M.T.K. and M.A.R. All authors have read and agree to the published version of the manuscript.

Funding: This research received no external funding.

Conflicts of Interest: The authors declare no conflict of interest. 


\section{References}

1. Duck, W.M.; Sobel, J.; Pruckler, J.M.; Song, Q.; Swerdlow, D.; Friedman, C.; Sulka, A.; Swaminathan, B.; Taylor, T.; Hoekstra, M.; et al. Antimicrobial Resistance Incidence and Risk Factors among Helicobacter pylori-Infected Persons, United States. Emerg. Infect. Dis. 2004, 10, 1088-1094. [CrossRef]

2. Guevara, B.; Cogdill, A.G. Helicobacter pylori: A Review of Current Diagnostic and Management Strategies. Dig. Dis. Sci. 2020, 65, 1917-1931. [CrossRef] [PubMed]

3. IARC Working Group on the Evaluation of Carcinogenic Risks to Humans. Schistosomes, Liver Flukes and Helicobacter Pylori; International Agency for Research on Cancer: Lyon, France, 1994; Volume 61.

4. Bray, F.; Ferlay, J.; Soerjomataram, I.; Siegel, R.L.; Torre, L.A.; Jemal, A. Global cancer statistics 2018: GLOBOCAN estimates of incidence and mortality worldwide for 36 cancers in 185 countries. CA A Cancer J. Clin. 2018, 68, 394-424. [CrossRef] [PubMed]

5. Verma, A.; Dubey, J.; Hegde, R.R.; Rastogi, V.; Pandit, J.K. Helicobacter pylori: Past, current and future treatment strategies with gastroretentive drug delivery systems. J. Drug Target. 2016, 24, 897-915. [CrossRef] [PubMed]

6. O'Connor, A.; Liou, J.; Gisbert, J.P.; O’Morain, C. Review: Treatment of Helicobacter pylori Infection. Helicobacter 2019, 24, e12640. [CrossRef]

7. Choi, Y.K.; Ahn, J.Y.; Won, S.H.; Jung, K.; Na, H.K.; Jung, K.W.; Kim, H.; Lee, J.H.; Choi, K.D.; Song, H.J.; et al. Eradication rate of Helicobacter pylori reinfection in Korea: A retrospective study. J. Gastroenterol. Hepatol. 2019, 34, 1696-1702. [CrossRef]

8. Savoldi, A.; Carrara, E.; Graham, D.Y.; Conti, M.; Tacconelli, E. Prevalence of Antibiotic Resistance in Helicobacter pylori: A Systematic Review and Meta-analysis in World Health Organization Regions. Gastroenterology 2018, 155, 1372-1382.e17. [CrossRef]

9. World Health Organization. WHO Publishes List of Bacteria for Which New Antibiotics are Urgently Needed. Available online: https:/www.who.int/news-room/detail/27-02-2017-who-publishes-list-of-bacteria-forwhich-new-antibiotics-are-urgently-needed (accessed on 1 May 2020).

10. Theuretzbacher, U.; Outterson, K.; Engel, A.; Karlen, A. The global preclinical antibacterial pipeline. Nat. Rev. Microbiol. 2019, 18, 275-285. [CrossRef]

11. Miró-Canturri, A.; Ayerbe-Algaba, R.; Smani, Y. Drug Repurposing for the Treatment of Bacterial and Fungal Infections. Front. Microbiol. 2019, 10, 41. [CrossRef]

12. Cai, J.; Han, C.; Hu, T.; Zhang, J.; Wu, D.; Wang, F.; Liu, Y.; Ding, J.; Chen, K.; Yue, J.; et al. Peptide deformylase is a potential target for Anti-Helicobacter pyloridrugs: Reverse docking, enzymatic assay, and X-ray crystallography validation. Protein Sci. 2006, 15, 2071-2081. [CrossRef]

13. Rout, S.; Patra, N.P.; Mahapatra, R.K. An in silico strategy for identification of novel drug targets against Plasmodium falciparum. Parasitol. Res. 2017, 116, 2539-2559. [CrossRef] [PubMed]

14. Fields, F.R.; Lee, S.W.; McConnell, M.J. Using bacterial genomes and essential genes for the development of new antibiotics. Biochem. Pharmacol. 2017, 134, 74-86. [CrossRef] [PubMed]

15. Wadood, A.; Ahmed, N.; Shah, L.; Ahmad, A.; Hassan, H.; Shams, S. In-silico drug design: An approach which revolutionarised the drug discovery process. OA Drug Des. Deliv. 2013, 1, 3. [CrossRef]

16. Chong, C.E.; Lim, B.-S.; Nathan, S.; Mohamed, R. In silico analysis of Burkholderia pseudomallei genome sequence for potential drug targets. Silico Boil. 2006, 6, 341-346.

17. Sarangi, A.N.; Aggarwal, R.; Rahman, Q.; Trivedi, N. Subtractive Genomics Approach for in Silico Identification and Characterization of Novel Drug Targets in Neisseria Meningitides Serogroup B. J. Comput. Sci. Syst. Boil. 2009, 2, 255-258. [CrossRef]

18. Shahid, F.; Ashfaq, U.A.; Saeed, S.; Munir, S.; Almatroudi, A.; Khurshid, M. In Silico Subtractive Proteomics Approach for Identification of Potential Drug Targets in Staphylococcus saprophyticus. Int. J. Environ. Res. Public Health 2020, 17, 3644. [CrossRef]

19. Solanki, V.; Tiwari, V. Subtractive proteomics to identify novel drug targets and reverse vaccinology for the development of chimeric vaccine against Acinetobacter baumannii. Sci. Rep. 2018, 8, 1-19. [CrossRef]

20. Uddin, R.; Jamil, F. Prioritization of potential drug targets against P. aeruginosa by core proteomic analysis using computational subtractive genomics and Protein-Protein interaction network. Comput. Boil. Chem. 2018, 74, 115-122. [CrossRef] 
21. Uddin, R.; Siraj, B.; Rashid, M.; Khan, A.; Halim, S.A.; Al-Harrasi, A. Genome Subtraction and Comparison for the Identification of Novel Drug Targets against Mycobacterium avium subsp. hominissuis. Pathogens 2020, 9, 368. [CrossRef]

22. Wadood, A.; Jamal, A.; Riaz, M.; Khan, A.; Uddin, R.; Jelani, M.; Azam, S.S. Subtractive genome analysis for in silico identification and characterization of novel drug targets in Streptococcus pneumonia strain JJA. Microb. Pathog. 2018, 115, 194-198. [CrossRef]

23. Dutta, A.; Singh, S.K.; Ghosh, P.; Mukherjee, R.; Mitter, S.; Bandyopadhyay, D. In silico identification of potential therapeutic targets in the human pathogen Helicobacter pylori. Silico Boil. 2006, 6, $43-47$.

24. Neelapu, N.R.R.; Pavani, T. Identification of novel drug targets in HpB38, HpP12, HpG27, Hpshi470, HpSJM180 strains of Helicobacter pylori: An in silico approach for therapeutic intervention. Curr. Drug Targets 2013, 14, 601-611. [CrossRef] [PubMed]

25. Neelapu, N.R.R.; Mutha, N.; Akula, S. Identification of Potential Drug Targets in Helicobacter pylori Strain HPAG1 by in silico Genome Analysis. Infect. Disord. Drug Targets 2015, 15, 106-117. [CrossRef] [PubMed]

26. Sarkar, M.; Maganti, L.; Ghoshal, N.; Dutta, C. In silico quest for putative drug targets in Helicobacter pylori HPAG1: Molecular modeling of candidate enzymes from lipopolysaccharide biosynthesis pathway. J. Mol. Model. 2012, 18, 1855-1866. [CrossRef]

27. Pasala, C.; Chilamakuri, C.S.R.; Katari, S.K.; Nalamolu, R.M.; Bitla, A.R.; Umamaheswari, A. An in silico study: Novel targets for potential drug and vaccine design against drug resistant H. pylori. Microb. Pathog. 2018, 122, 156-161. [CrossRef]

28. Yeh, I.; Hanekamp, T.; Tsoka, S.; Karp, P.D.; Altman, R.B. Computational Analysis of Plasmodium falciparum Metabolism: Organizing Genomic Information to Facilitate Drug Discovery. Genome Res. 2004, 14, 917-924. [CrossRef]

29. Raman, K.; Yeturu, K.; Chandra, N.R. targetTB: A target identification pipeline for Mycobacterium tuberculosis through an interactome, reactome and genome-scale structural analysis. BMC Syst. Boil. 2008, 2, 109. [CrossRef]

30. Wishart, D.S.; Feunang, Y.D.; Guo, A.C.; Lo, E.J.; Marcu, A.; Grant, J.R.; Sajed, T.; Johnson, D.; Li, C.; Sayeeda, Z.; et al. DrugBank 5.0: A major update to the DrugBank database for 2018. Nucleic Acids Res. 2018, 46, D1074-D1082. [CrossRef]

31. Kanehisa, M.; Goto, S. KEGG: Kyoto Encyclopedia of Genes and Genomes. Nucleic Acids Res. 2000, 28, 27-30. [CrossRef]

32. Kanehisa, M.; Sato, Y. KEGG Mapper for inferring cellular functions from protein sequences. Protein Sci. 2020, 29, 28-35. [CrossRef]

33. Kanehisa, M.; Sato, Y.; Furumichi, M.; Morishima, K.; Tanabe, M. New approach for understanding genome variations in KEGG. Nucleic Acids Res. 2019, 47, D590-D595. [CrossRef] [PubMed]

34. Pearson, W.R. Selecting the Right Similarity-Scoring Matrix. Curr. Protoc. Bioinform. 2013, 43, 3.5.1-3.5.9. [CrossRef] [PubMed]

35. Butt, A.M.; Tahir, S.; Nasrullah, I.; Idress, M.; Lu, J.; Tong, Y. Mycoplasma genitalium: A comparative genomics study of metabolic pathways for the identification of drug and vaccine targets. Infect. Genet. Evol. 2012, 12, 53-62. [CrossRef] [PubMed]

36. Damte, D.; Suh, J.-W.; Lee, S.-J.; Yohannes, S.B.; Hossain, A.; Park, S.-C. Putative drug and vaccine target protein identification using comparative genomic analysis of KEGG annotated metabolic pathways of Mycoplasma hyopneumoniae. Genomics 2013, 102, 47-56. [CrossRef]

37. Jadhav, A.; Shanmugham, B.; Rajendiran, A.; Pan, A. Unraveling novel broad-spectrum antibacterial targets in food and waterborne pathogens using comparative genomics and protein interaction network analysis. Infect. Genet. Evol. 2014, 27, 300-308. [CrossRef] [PubMed]

38. Zhang, R.; Lin, Y. DEG 5.0, a database of essential genes in both prokaryotes and eukaryotes. Nucleic Acids Res. 2009, 37, D455-D458. [CrossRef]

39. Ramos, P.I.P.; Porto, D.A.F.D.; Lanzarotti, E.; Sosa, E.J.; Burguener, G.; Pardo, A.; Klein, C.C.; Sagot, M.-F.; Vasconcelos, A.T.R.; Gales, A.C.; et al. An integrative, multi-omics approach towards the prioritization of Klebsiella pneumoniae drug targets. Sci. Rep. 2018, 8, 1-19. [CrossRef]

40. Barh, D.; Tiwari, S.; Jain, N.; Ali, A.; Santos, A.R.; Misra, A.N.; Azevedo, V.; Kumar, A. In silico subtractive genomics for target identification in human bacterial pathogens. Drug Dev. Res. 2010, 72, 162-177. [CrossRef] 
41. Benites, J.; Toledo, H.; Salas, F.; Guerrero, A.; Rios, D.; Valderrama, J.A.; Calderon, P.B. In Vitro Inhibition ofHelicobacter pyloriGrowth by Redox Cycling Phenylaminojuglones. Oxidative Med. Cell. Longev. 2018, 2018, 1-8. [CrossRef]

42. Satuluri, S.H.; Katari, S.K.; Pasala, C.; Amineni, U. Novel and potent inhibitors for dihydropteroate synthase of Helicobacter pylori. J. Recept. Signal Transduct. 2020, 40, 246-256. [CrossRef]

43. Song, Z.; Fu, W.; Zhou, L. Cefuroxime, levofloxacin, esomeprazole, and bismuth as first-line therapy for eradicating Helicobacter pylori in patients allergic to penicillin. BMC Gastroenterol. 2019, 19, 132. [CrossRef]

44. Dwyer, D.J.; Belenky, P.; Yang, J.H.; Macdonald, I.C.; Martell, J.D.; Takahashi, N.; Chan, C.T.Y.; Lobritz, M.A.; Braff, D.; Schwarz, E.G.; et al. Antibiotics induce redox-related physiological alterations as part of their lethality. Proc. Natl. Acad. Sci. USA 2014, 111, E2100-E2109. [CrossRef] [PubMed]

45. Kim, J.; Xiao, H.; Bonanno, J.B.; Kalyanaraman, C.; Brown, S.; Tang, X.; Al-Obaidi, N.; Patskovsky, Y.; Babbitt, P.C.; Jacobson, M.P.; et al. Structure-guided discovery of the metabolite carboxy-SAM that modulates tRNA function. Nature 2013, 498, 123-126. [CrossRef] [PubMed]

46. Chopra, S.; Reader, J.S. tRNAs as Antibiotic Targets. Int. J. Mol. Sci. 2015, 16, 321-349. [CrossRef] [PubMed]

47. Lee, K.H.; Park, S.Y.; Jeong, S.J.; Jung, D.H.; Kim, J.-H.; Jeong, S.H.; Kang, I.-M.; Song, Y.G. Can Aminoglycosides Be Used as a New Treatment for Helicobacter pylori? In vitro Activity of Recently Isolated Helicobacter pylori. Infect. Chemother. 2019, 51, 10-20. [CrossRef] [PubMed]

48. Foynes, S.; Dorrell, N.; Ward, S.J.; Stabler, R.A.; McColm, A.A.; Rycroft, A.N.; Wren, B.W. Helicobacter pylori Possesses Two CheY Response Regulators and a Histidine Kinase Sensor, CheA, Which Are Essential for Chemotaxis and Colonization of the Gastric Mucosa. Infect. Immun. 2000, 68, 2016-2023. [CrossRef] [PubMed]

49. Walia, G.; Kumar, P.; Surolia, A. The Role of UPF0157 in the Folding of M. tuberculosis Dephosphocoenzyme A Kinase and the Regulation of the Latter by CTP. PLoS ONE 2009, 4, e7645. [CrossRef]

50. Spry, C.; Kirk, K.; Saliba, K.J. Coenzyme A biosynthesis: An antimicrobial drug target. FEMS Microbiol. Rev. 2008, 32, 56-106. [CrossRef]

51. Kavermann, H.; Burns, B.P.; Angermüller, K.; Odenbreit, S.; Fischer, W.; Melchers, K.; Haas, R. Identification and Characterization of Helicobacter pylori Genes Essential for Gastric Colonization. J. Exp. Med. 2003, 197, 813-822. [CrossRef]

52. Yeo, H.-J.; Savvides, S.N.; Herr, A.B.; Lanka, E.; Waksman, G. Crystal Structure of the Hexameric Traffic ATPase of the Helicobacter pylori Type IV Secretion System. Mol. Cell 2000, 6, 1461-1472. [CrossRef]

53. Ansari, S.; Yamaoka, Y. Survival of Helicobacter pylori in gastric acidic territory. Helicobacter 2017, 22, e12386. [CrossRef] [PubMed]

54. Backert, S.; Tegtmeyer, N.; Fischer, W. Composition, structure and function of theHelicobacter pylori cagpathogenicity island encoded type IV secretion system. Future Microbiol. 2015, 10, 955-965. [CrossRef]

55. Nilsson, C.; Sillén, A.; Eriksson, L.; Strand, M.-L.; Enroth, H.; Normark, S.; Falk, P.; Engstrand, L. Correlation between cag Pathogenicity Island Composition and Helicobacter pylori-Associated Gastroduodenal Disease. Infect. Immun. 2003, 71, 6573-6581. [CrossRef]

56. Totsika, M. Benefits and Challenges of Antivirulence Antimicrobials at the Dawn of the Post-Antibiotic Era. Drug Deliv. Lett. 2016, 6, 30-37. [CrossRef]

57. Altieri, A.S.; Kelman, Z. DNA Sliding Clamps as Therapeutic Targets. Front. Mol. Biosci. 2018, 5, 87. [CrossRef] [PubMed]

58. Pandey, P.; Verma, V.; Gautam, G.; Kumari, N.; Dhar, S.K.; Gourinath, S. Targeting the $\beta$-clamp in Helicobacter pylori with FDA-approved drugs reveals micromolar inhibition by diflunisal. FEBS Lett. 2017, 591, $2311-2322$. [CrossRef] [PubMed]

59. Kling, A.; Lukat, P.; Almeida, D.V.; Bauer, A.; Fontaine, E.; Sordello, S.; Zaburannyi, N.; Herrmann, J.; Wenzel, S.C.; König, C.; et al. Targeting DnaN for tuberculosis therapy using novel griselimycins. Science 2015, 348, 1106-1112. [CrossRef] [PubMed]

60. Hong, W.; Zeng, J.; Xie, J. Antibiotic drugs targeting bacterial RNAs. Acta Pharm. Sin. B 2014, 4, $258-265$. [CrossRef] [PubMed]

61. Heath, R.J.; White, W.S.; Rock, C.O. Lipid biosynthesis as a target for antibacterial agents. Prog. Lipid Res. 2001, 40, 467-497. [CrossRef]

62. Pereira, L.; Hoover, T.R. Stable Accumulation of $\sigma 54$ in Helicobacter pylori Requires the Novel Protein HP0958. J. Bacteriol. 2005, 187, 4463-4469. [CrossRef] 
63. Mu, W.; Yu, S.; Zhu, L.; Zhang, T.; Jiang, B. Recent research on 3-phenyllactic acid, a broad-spectrum antimicrobial compound. Appl. Microbiol. Biotechnol. 2012, 95, 1155-1163. [CrossRef] [PubMed]

64. Adamczak, A.; Ożarowski, M.; Karpiński, T.M. Antibacterial Activity of Some Flavonoids and Organic Acids Widely Distributed in Plants. J. Clin. Med. 2020, 9, 109. [CrossRef] [PubMed]

65. Feng, S.; Zeng, W.; Luo, F.; Zhao, J.; Yang, Z.; Sun, Q. Antibacterial activity of organic acids in aqueous extracts from pine needles (Pinus massoniana Lamb.). Food Sci. Biotechnol. 2010, 19, 35-41. [CrossRef]

66. Jadamus, A.; Vahjen, W.; Simon, O. Studies on the mode of action of probiotics: Effects of the spore-specific dipicolinic acid on selected intestinal bacteria. J. Agric. Sci. 2005, 143, 529-535. [CrossRef]

67. Coban, H.B. Organic acids as antimicrobial food agents: Applications and microbial productions. Bioprocess. Biosyst. Eng. 2020, 43, 569-591. [CrossRef] [PubMed]

68. Hu, C.; Ren, L.; Zhou, Y.; Ye, B. Characterization of antimicrobial activity of three Lactobacillus plantarum strains isolated from Chinese traditional dairy food. Food Sci. Nutr. 2019, 7, 1997-2005. [CrossRef]

69. Kim, S.; Chen, J.; Cheng, T.; Gindulyte, A.; He, J.; He, S.; Li, Q.; Shoemaker, B.A.; Thiessen, P.A.; Yu, B.; et al. PubChem 2019 update: Improved access to chemical data. Nucleic Acids Res. 2019, 47, D1102-D1109. [CrossRef]

70. Ricke, S.C. Perspectives on the use of organic acids and short chain fatty acids as antimicrobials. Poult. Sci. 2003, 82, 632-639. [CrossRef]

71. Chen, X.; Liu, X.-M.; Tian, F.; Zhang, Q.; Zhang, H.-P.; Zhang, H.; Chen, W. Antagonistic Activities of Lactobacilli against Helicobacter pylori Growth and Infection in Human Gastric Epithelial Cells. J. Food Sci. 2012, 77, M9-M14. [CrossRef]

72. Lin, W.-H.; Lin, C.-K.; Sheu, S.-J.; Hwang, C.-F.; Ye, W.-T.; Hwang, W.-Z.; Tsen, H.-Y. Antagonistic Activity of Spent Culture Supernatants of Lactic Acid Bacteria against Helicobacter Pylori Growth and Infection in Human Gastric Epithelial AGS Cells. J. Food Sci. 2009, 74, M225-M230. [CrossRef]

73. Matsushima, M.; Suzuki, T.; Masui, A.; Kasai, K.; Kouchi, T.; Takagi, A.; Shirai, T.; Mine, T. Growth inhibitory action of cranberry onHelicobacter pylori. J. Gastroenterol. Hepatol. 2008, 23, S175-S180. [CrossRef] [PubMed]

74. Na, J.-H.; An, Y.J.; Cha, S.-S. GMP and IMP Are Competitive Inhibitors of CMY-10, an Extended-Spectrum Class C $\beta$-Lactamase. Antimicrob. Agents Chemother. 2017, 61, e00098-17. [CrossRef] [PubMed]

75. Na, J.-H.; Lee, T.H.; Park, S.-B.; Kim, M.-K.; Jeong, B.-G.; Chung, K.M.; Cha, S.-S. In vitro and in vivo Inhibitory Activity of NADPH Against the AmpC BER Class C $\beta$-Lactamase. Front. Cell. Infect. Microbiol. 2018, 8, 441. [CrossRef] [PubMed]

76. Bai, J.; Wu, Y.; Zhong, K.; Xiao, K.; Liu, L.; Huang, Y.; Wang, Z.; Gao, H. A Comparative Study on the Effects of Quinic Acid and Shikimic Acid on Cellular Functions of Staphylococcus aureus. J. Food Prot. 2018, 81, 1187-1192. [CrossRef]

77. Mehla, K.; Ramana, J. Novel Drug Targets for Food-Borne Pathogen Campylobacter jejuni: An Integrated Subtractive Genomics and Comparative Metabolic Pathway Study. OMICS 2015, 19, 393-406. [CrossRef]

78. Zazgornik, J.; Mittermayer, H. Citric acid inhibits growth of Helicobacter pylori in vitro: A new strategy for eradication. Wien. Klin. Wochenschr. 2011, 123, 38-40. [CrossRef]

79. Karp, P.D.; Billington, R.; Caspi, R.; Fulcher, C.A.; Latendresse, M.; Kothari, A.; Keseler, I.M.; Krummenacker, M.; Midford, P.E.; Ong, Q.; et al. The BioCyc collection of microbial genomes and metabolic pathways. Brief. Bioinform. 2019, 20, 1085-1093. [CrossRef]

80. Altschul, S.F.; Gish, W.; Miller, W.; Myers, E.W.; Lipman, D.J. Basic local alignment search tool. J. Mol. Biol. 1990, 215, 403-410. [CrossRef]

81. Luo, H.; Lin, Y.; Gao, F.; Zhang, Z.; Zhang, R. DEG 10, an update of the database of essential genes that includes both protein-coding genes and noncoding genomic elements. Nucleic Acids Res. 2014, 42, D574-D580. [CrossRef]

82. Zhang, R.; Ou, H.; Zhang, C. DEG: A database of essential genes. Nucleic Acids Res. 2004, 32, D271-D272. [CrossRef]

83. Yu, N.Y.; Wagner, J.R.; Laird, M.R.; Melli, G.; Rey, S.; Lo, R.; Dao, P.; Sahinalp, S.C.; Ester, M.; Foster, L.J.; et al. PSORTb 3.0: Improved protein subcellular localization prediction with refined localization subcategories and predictive capabilities for all prokaryotes. Bioinformics 2010, 26, 1608-1615. [CrossRef] [PubMed] 
84. Piccolomini, R.; Di Bonaventura, G.; Catamo, G.; Carbone, F.; Neri, M. Comparative evaluation of the E test, agar dilution, and broth microdilution for testing susceptibilities of Helicobacter pylori strains to 20 antimicrobial agents. J. Clin. Microbiol. 1997, 35, 1842-1846. [CrossRef] [PubMed]

85. Clinical and Laboratory Standards Institute (CLSI). Methods for Antimicrobial Dilution and Disk Susceptibility Testing of Infrequently Isolated or Fastidious Bacteria, 3rd ed.; CLSI Guidline M45; CLSI: Wayne, PA, USA, 2015. 